Cahiers $d u$ MONDE RUSSE

\section{Cahiers du monde russe}

Russie - Empire russe - Union soviétique et États indépendants

42/2-4 | 2001

La police politique en Union soviétique, 1918-1953

\title{
Social disorder, mass repression, and the NKVD during the 1930s.
}

DAVID R. SHEARER

\section{OpenEdition}

Journals

Édition électronique

URL : https://journals.openedition.org/monderusse/8465

DOI : $10.4000 /$ monderusse. 8465

ISSN : $1777-5388$

Éditeur

Éditions de l'EHESS

Édition imprimée

Date de publication : 1 avril 2001

Pagination : 505-534

ISBN : 2-7132-1398-3

ISSN : $1252-6576$

Référence électronique

DAVID R. SHEARER, «Social disorder, mass repression, and the NKVD during the 1930s. », Cahiers du monde russe [En ligne], 42/2-4 | 2001, mis en ligne le 01 janvier 2007, consulté le 02 septembre 2022 URL : http://journals.openedition.org/monderusse/8465; DOI : https://doi.org/10.4000/monderusse. 8465 
chercher : repérer : avancer

Cet article est disponible en ligne à l'adresse :

http://www.cairn.info/article.php?ID REVUE=CMR\&ID NUMPUBLIE=CMR 422\&ID ARTICLE=CMR 4220505

Social disorder, mass repression, and the NKVD during the 1930s

par DAVID R. SHEARER

| Editions de l'EHESS | Cahiers du monde russe

2001/2-3-4 - Vol 42

ISSN 1252-6576 | ISBN 2713213983 | pages 505 à 534

Pour citer cet article :

-SHEARER D., Social disorder, mass repression, and the NKVD during the 1930s, Cahiers du monde russe 2001/2-3-4, Vol 42, p. 505-534.

Distribution électronique Cairn pour les Editions de l'EHESS.

(C) Editions de l'EHESS. Tous droits réservés pour tous pays.

La reproduction ou représentation de cet article, notamment par photocopie, n'est autorisée que dans les limites des conditions générales d'utilisation du site ou, le cas échéant, des conditions générales de la licence souscrite par votre établissement. Toute autre reproduction ou représentation, en tout ou partie, sous quelque forme et de quelque manière que ce soit, est interdite sauf accord préalable et écrit de l'éditeur, en dehors des cas prévus par la législation en vigueur en France. Il est précisé que son stockage dans une base de données est également interdit. 
DAVID R. SHEARER

\section{SOCIAL DISORDER, MASS REPRESSION, AND THE NKVD DURING THE 1930s*}

\section{Introduction}

This paper examines the origins of mass repression during the 1930s by focusing on the evolving policies of the People's Commissariat of Internal affairs, the NKVD (Narodnyi komissariat vnutrennikh del). The NKVD included both the regular police - the militsiia - and the organs of state security, the Glavnoe upravlenie gosudarstvennoi bezopasnosti - GUGB. The predecessor to the GUGB was the $O b^{\prime \prime}$ dinennoe gosudarstvennoe politicheskoe upravlenie, or OGPU. Although administratively linked throughout the 1930s, the police and the OGPU/GUGB were supposed to have different functions. The police were charged to fight crime and to maintain social order. The OGPU/GUGB was charged to protect the Soviet state and its leaders from the country's political enemies. I will show that, early in the 1930s, these two functions merged in the policies of the police and the OGPU. Solving problems of mass social disorder became synonymous with the political protection of the state and defined a major priority for political leaders and high officials of the OGPU/NKVD. That priority was reflected in the primacy given to operational policies of social cleansing and mass social re-organization. Throughout the mid-1930s, especially, wide-scale police operations targeted criminals and other marginal social groups, which officials perceived not just as socially harmful but as politically dangerous, a threat to the Soviet state and to the construction of socialism in the USSR. I will examine the reasons why the functions of social order and state security became linked in the 1930s and I will explore the consequences of this linkage in the changing character of the state's policies of repression.

* Research for this paper was made possible by grants from the International Research and Exchanges Board, the National Council for Eurasian and East European Research, the National Endowment for the Humanities, and the University of Delaware. I am grateful for the support of these organizations. 
Campaigns of mass repression targeted different groups at different times and were not all directed against criminal or socially marginal populations. The largest mass operations, of course, were those associated with dekulakization in the early 1930 s, the state's attempt to destroy organized class resistance in the countryside. Party and police officials focused dekulakization campaigns on property confiscation and execution, imprisonment, or exile of supposedly rich peasants - kulaks - and other rural anti-Soviet elements. After 1933, police shifted attention away from class war in the rural areas to cleanse the country's major cities, as well as other strategic regions - borderlands, new industrial centers, and even resort areas of the political elite. Yet even as the criterion of class became less prominent in the state's campaigns of social repression, the range of groups which police and security organs regarded as potentially dangerous broadened. During the course of the decade, police applied methods of mass repression against an increasing number of ethnic and national minorities, as well as against criminal and other socially marginal categories. The state's policies of mass repression reached their apogee in 1937 and 1938. Operations associated with the Great Purges of those years encompassed nearly every group that had, at one time or another, become marginalized or politically suspect during the 1930s: so-called kulaks, criminals and socially marginal populations, and national minorities, including large numbers of political refugees. I will focus attention primarily on the background to the 1937 and 1938 repressions, but it should be noted that mass operations did not end with the repressions of those years. Campaigns, especially against certain national minorities and ethnic populations, continued well into the 1940s. ${ }^{1}$

I believe that resolving problems of social order provided a major motivation for the mass repressions at the end of the decade, but so was the increasing threat of war during the late 1930s. I will explore how the threat of war shaped leaders' perception of politically suspect populations as the social basis for a potential uprising in case of invasion. I agree with those who argue that the mass repressions of the late 1930s were a prophylactic response to this potential threat rather than the reaction of the regime to an ongoing crisis of social chaos. In making this argument, I am revising my own earlier assessment of the mass repressions as a response to an ongoing crisis of social order. ${ }^{2}$

Throughout this paper, I will examine the politics of policy formation at high levels of the NKVD, the party, and the Soviet state, but I will also explore the problems of implementing policies at local levels and the social consequences of state policies. While I rely largely on information from central state and party

1. See, for example, A. E. Gur'ianov, ed., Represii protiv Poliakova i pol'skikh grazhdan (Moscow, 1997); Terry Martin, "The origins of Soviet ethnic cleansing," Journal of Modern History, 70 (December 1998): 813-861, especially 847-850; Aleksandr Nekrich, The punished peoples: The deportation and fate of Soviet minorities at the end of the Second World War (New York, 1978); I. L. Shcherbakova, ed., Nakazannyi narod: repressii protiv rossiiskikh nemtsev (Moscow, 1999); V. N. Zemskov, "Prinuditel'nye migratsii iz Pribaltiki v 1940-1950kh godakh," Otechestvennaia istoriia, 1 (1992): 4-19.

2. David R. Shearer, "Crime and social disorder in Stalin's Russia: A reassessment of the Great Retreat and the origins of mass repression," Cahiers du Monde russe, 39, 1-2 (1998): 119-148. 
archives, I will focus parts of my paper on the Western Siberia district, or krai. I have chosen Western Siberia because that area exemplified, in some ways in the extreme, many of the trends that occurred in other parts of the country. Records from the administrative center of the district in Novosibirsk reflect well how central policies worked, or did not work, in practice. I will argue that, by the late 1930s, party and state leaders believed that policies of mass repression and re-organization of the country's population had resolved many of the problems of social disorder, which they had perceived as so threatening. The increasing possibility of war, however, aroused fears, not of social disorder, but of organized uprisings by disaffected and marginal segments of the population. Party and NKVD records reveal the mechanism, social context, and motivation for the mass repression of 1937 and 1938.

\section{The February-March 1937 plenary sessions}

In late February and early March 1937, several hundred leading functionaries of the ruling Communist Party of the Soviet Union gathered in Moscow for a plenary session of the party's executive body, the Central Committee. N. I.Ezhov, one of the party's leading secretaries and head of the People's Commissariat of the Interior, the NKVD, delivered one of the major speeches at the session. Ezhov's remarks are worth recalling. Although highly politicized, Ezhov's speech provides one of the few candid overviews of the NKVD's work for the previous years of the 1930s. ${ }^{3}$

Ezhov's remarks amounted to a harsh indictment of NKVD policies and a damning criticism of the previous head of the Commissariat, Genrikh Iagoda. Ezhov charged Iagoda and the NKVD with having failed to protect the party and the country from the threat of political sabotage by opposition organizations inside the country and enemy intelligence services working from outside the Soviet Union. Instead of using its resources to expose underground political organizations and agents of foreign governments, the GUGB, Ezhov charged, had dissipated its energies in chasing criminals and fighting social disorder. This was the business of the police, the militsiia, chided Ezhov, not the work of the organs of state security. Ezhov cited figures from 1935 and 1936, acknowledging that the NKVD, in particular the GUGB, had arrested a "significant number" of people, "but when we analyze the crimes for which these people were arrested," Ezhov continued, "it turns out that eighty percent [of those crimes] had no connection to [the function of] the UGB." According to Ezhov, the great majority of people arrested by the UGB were arrested for offenses such as "professional-white collar crimes, for petty crimes, for hooliganism, petty theft, etc.; that is, people who should have been arrested by the civil police or the procuracy organs, but who were arrested by the UGB.” By paying so much attention to fighting ordinary crime, the UGB had

3. Rossiiskii Gosudarstvennyi Arkhiv Sotsial'no-Politicheskoi Istorii (RGASPI), f. 17, op. 2, d. 597, 11. 1-68. 
"fettered" itself; the state security organs had neglected their agent work and investigations of serious political crimes. ${ }^{4}$

If the overall direction of NKVD policies was wrong, so were its methods of work. Ezhov summarized the campaigns of mass repression against anti-Soviet kulak peasants in the early 1930s as a peculiarity of that period of large-scale, open class war. Such methods were justified then, according to Ezhov, when the party fought an all out struggle for dekulakization of the countryside and collectivization of agriculture. By 1933, however, the major struggle for collectivization had been won. Kulaks had been defeated as a class. As Ezhov reminded his audience, however, the victory of socialism in the USSR did not mean the end of class war. Class enemies were no longer able to defeat Soviet power through direct confrontation, and so the party's enemies changed tactics to wage a war of underground sabotage. This change in tactics by the enemies of socialism required, in turn, a change in tactics by the party, by Soviet institutions, and most of all by the organs of state security, the UGB. Ezhov recalled the directives of the party and the government, and speeches by party leaders, including Stalin, about the sharpening of class war, about the "quiet sabotage" (tikhii zapoi) of enemies, and about how to meet this new challenge. New methods of class war required new methods of operation, Ezhov said, but the NKVD had failed to reorient itself. "It is one thing," Ezhov declared, "to route mass kulak organizations in the earlier period, but another to uncover diversionaries and spies who hide behind the mask of loyalty to Soviet power." 5 Ezhov charged that the UGB had failed to give priority to development of an effective agent and investigative apparatus. Instead, the organs of state security continued "automaton-like" to employ the "mass work" and "campaign-style methods" of the past. ${ }^{6}$

Ezhov tailored his speech to discredit Iagoda and to justify the purge of the NKVD, which had already started in late $1936 .{ }^{7}$ Yet if Ezhov tailored his facts to fit his political ends, he nonetheless gave to plenary delegates a roughly accurate account of NKVD policies and methods during the previous years. Throughout most of the 1930s, OGPU and then NKVD policies had been directed toward combating crime and social disorder. And given the inadequacies of regular policing methods in the country, OGPU and NKVD officials resorted to large-scale campaigns to arrest, remove, or otherwise contain what leaders regarded as socially harmful or politically suspect populations. These campaigns grew out of the mass

4. RGASPI, f. 17, op. 2, d. 597, 1. 10. The UGB was the regional administrative system of the Chief Administration of State Security, the GUGB.

5. RGASPI, f. 17, op. 2, d. 597,1.15.

6. RGASPI, f. 17, op. 2, d. 597, 1. 8-9.

7. In September 1936, Ezhov, upon Stalin's recommendation, replaced Iagoda as chief of the NKVD. Iagoda was not yet under arrest. At the time of the plenary session, he was head of the communications commissariat. Iagoda took part in the plenary session. He acknowledged his failure to understand and follow the proper political line in directing the work of the GUGB. He claimed that if he had not been so preoccupied with administration of the NKVD as a whole, he could have given more attention to the GUGB in particular. RGASPI, f. 17, op. 2, d. 596, 1. 40. 
repressions, which the OGPU used during dekulakization and collectivization of the countryside during the early 1930s, and they resembled the campaigns that the GUGB and police used during the mass repressions of 1937 and 1938. Ezhov denounced these policies and methods in 1937 as a grievous political mistake, and even worse as part of a plan of counter-revolutionary sabotage. Yet what Ezhov described as political error in 1937 was party and state policy during much of the decade. Throughout the early and middle years of the 1930s, party and state leaders perceived social disorder as the primary threat to the stability of the Soviet state and to the construction of socialism. And rightly so. Police, party, and state agencies struggled to cope with massive social and economic dislocation caused by the state's crash industrialization program and by the social war of collectivization in the countryside. Leaders gave to social disorder political overtones that arose out of the chaos and class war of the first years of the decade. The political cast that authorities gave to the social chaos of the early 1930s may or may not have had a basis in social reality, but the chaos was real.

\section{The civil police and the OGPU}

A NKVD report from April 1930 addressed the problem of social disorder bluntly. The report stated that police numbers were "entirely inadequate" for the tasks forced upon them by the state's socialist offensive. The state could count on only 90,000 regular police officers in the whole of the RSFSR in 1930. This included 33,563 regular or state police, nearly 53,000 police hired specifically to protect enterprises (vedmilitsiia), and 4,441 special investigative detectives (ugolovnyi rozysk). This number, reduced by 1,000 from the previous year, constituted a force some four times smaller than that which maintained order in 1913, the last peacetime year of the old regime. ${ }^{8}$ Moreover, most of these police were concentrated in cities and industrial centers, leaving only 12,887 policemen to protect state interests and to keep public order in rural areas of the RSFSR. In the early 1930s, rural police were nearly bereft of transport, which included horses, let alone automobiles. Many regional police forces were lucky if they had one horse for the whole region. In the Trotsk region of Leningrad oblast', the police apparatus could rely on two horses, if available, stabled and owned by a local medical clinic and a village soviet. Instead of a minimum of two special police undercover agents per village, most rural regional police organization had to make do with just one agent per region, or raion. Many regional police forces had no special investigative agents. ${ }^{9}$

8. Gosudarstvennyi Arkhiv Rossiiskoi Federatsii (GARF), f. 393, op. 84, d. 24, 1. 10. A. V. Borisov, A. N. Dugin, A. Ia. Malygin et al., Politsiia $i$ militsiia Rossii: stranitsy istorii (Moscow, 1995); V. M. Kuritsyn, Istoriia gosudarstva i prava Rossii, 1929-1940 (Moscow, 1998); L. P. Rasskazov, Karatel'nye organy $v$ protsesse formirovaniia i funktsionirovaniia administrativno-komandnoi sistemy $v$ sovetskom gosudarstve, 1917-1941 (Ufa, 1994).

9. GARF, f. 393, op. 84, d. 24,1.14. See also the description of police activities and problems in the Trotsk rural region of Leningrad oblast', 1928-1929. GARF, f. 393, op. 78, d. 21. 
In a 1932 report to the highest government council, Sovnarkom, Genrikh Iagoda, assistant head of the OGPU, lamented that, at its current strength, the police could not, "in a single republic, krai, or oblast'," fulfill the tasks of maintaining revolutionary order in the country. Iagoda described as "especially strained" regions of new industrial and transportation construction "where populations grow at a rapid tempo and draw an influx of criminal elements." 10 The largest accumulations of kulak and anti-Soviet elements were also to be found, logically, in areas of the country designated for exile and special settlements. With its penal settlements in the north and new industrial centers in the southwest, the Western Siberian district fit Iagoda's description as an "especially strained" area. He singled out the district as one of several areas severely understaffed by police and "not well defended."11

Reports from Western Siberian police and OGPU officials confirmed Iagoda's laconic assessment. As the numbers and proportion of socially dangerous populations rose rapidly in Western Siberia, the number of police in fact dropped in the very early years of the decade. Reorganization and purging of police ranks in 1930 and 1931 resulted in a reduction of civil police in the district from 2,736 to 2,327. In Novosibirsk, the number of police dropped from 276 to 197 as the population grew from 146,000 to 180,000 . In the provincial center of Bisk, in the industrial and agricultural lands west of Novosibirsk, only 69 police officers served a city of 53,000 in 1932. In Novo-Kuznetsk, the number of police officials actually increased in 1930 and 1931 from 24 to 38, but the population during the same year soared from 28,000 to $170,000 . .^{12}$ In Novosibirsk, police ranks were stretched so thin and jails so overcrowded that prison officials allowed prisoners to "guard" themselves. Prisoners came and went, "as they please, individually and in groups."13 In rural areas, the lack of police and OGPU units required one chief inspector, along with two to three officers, to cover approximately forty to fortyfive square kilometers and 10,000 or more inhabitants. In non-Russian areas of the krai, Soviet police authority hardly existed. ${ }^{14}$

If the numbers of police were low, so were the qualifications of police personnel. In the early 1930s, the police in Western Siberia, as in many other

10. Iagoda reported a total police force in 1932 of 98,292 , which included cadets as well as street officers and command staff. GARF, f. 5446, op. 13a, d. 1320, 1. 5. See also TsIK (RSFSR) report on police in GARF, f. 1235, op. 141, d. 910, 11. 24-40.

11. GARF, f. 5446, op. 13a, d. 1320,1.6.

12. These figures are included in the police report from January 1932. Gosudarstvennyi Arkhiv Novosibirskoi Oblasti (GANO), I, f. 47, op. 5, d. 160, 11.6-7.

13. GANO, I, f. 47 , op. 5 , d. $160,1.44$.

14. GARF, f. 5446, op. 14a, d. 762,1. 7. The average ratio of police to inhabitants for the whole of the RSFSR, including both cities and rural areas, in 1930 was 1: 5,371, with one policeman per 916 square km. GARF, f. 393, op. 84, d. 24, 1. 13ob. In 1932, according to Iagoda, in Moscow and other major urban areas, there was one policeman on the average for every 7501,000 inhabitants, although even in these centers, peripheral or poor working-class neighborhoods were poorly policed. GARF, f. 5446, op. 13a, d. 1320, 1. 6. David Hoffman, Peasant metropolis: Social identities in Moscow, 1928-1941 (Ithaca, 1994). 
regions of the country, were an ill-trained, ill-equipped, and low-paid lot. Although reorganization in late 1929 and early 1930 placed the RKM (RabocheKrest'ianskaia Militsiia) under OGPU administration, police forces were still funded out of the budgets of district- and local-level soviets. Local governments were also supposed to supply police with apartments allocated out of their living funds. Yet, a 1932 police report condemned the "total indifference" of local soviet governments to the needs of the police. ${ }^{15}$ Despite their obligations, krai and raionlevel executive committees constantly paid wage sums late, mostly because the money was siphoned off to other priorities. A 1933 letter from the district's police chief, M. Domarev, to the head of district Soviet Executive Committee, Fedor Griadinskii, complained that failure of the krai and raion-level soviets to provide adequate food supplies for local police was resulting in widespread corruption. This kind of corruption included outright theft and speculation in food and meat supplies, extortion of produce and meat from collective and state farms, and other forms of activity by official agencies that tied them to local criminal elements. ${ }^{16}$

Housing shortages for police were chronic. In the Western Siberian district, which reflected trends in the rest of the country, only $5 \%$ of the police force lived in state-allocated apartments. Most paid rent out of their meager salaries for rooms or small apartments in private houses. The situation in Novosibirsk was "especially extreme." Half the police force in that city was forced to rent private dwellings, while $6 \%$ were registered as homeless. ${ }^{17}$ The average monthly pay even for an investigative inspector was only 110-130 rubles in 1932, although this was supposed to be raised to $120-130$ rubles in 1933. This was lower than the average monthly salary of an unskilled worker in the non-priority consumer sectors of the economy. The head of a local police station earned 60 to 70 rubles monthly, about as much as a sales clerk, and a rank and file policeman drew only 50 to 60 rubles monthly. ${ }^{18}$ By mid-decade, the militsiia received pay and ration cards and training equal to that of troops of the political police. In 1932, however, most police officers were still on the second-tier ration list with access to fewer goods and goods of lower quality than groups on the state's first ration list.

Police work, even at the investigative and operational level, attracted few young and vigorous workers. The 1932 police report cited above declared that only 20 to $25 \%$ of the district's police officers were physically fit enough to carry out their full range of duties. This was especially true of the higher ranks, above the level of a patrol officer. Due to low pay and poor housing priorities, noted the report, the police profession seemed to attract "right and left (splosh' i riadom) [...] physical invalids or people in very weak health." 19 Only $34 \%$ of the district's police force was equipped with weapons in working order, few patrol officers had proper

15. GANO, I, f. 47 , op. 5 , d. $160,1.32$.

16. GANO, I, f. 47 , op. 5 , d. $160,11.26,29,32,36-37$.

17. GANO, I, f. 47 , op. 5 , d. $160,1.28$.

18. GANO, I, f. 47 , op. 5 , d. $160,1.31$.

19. GANO, I, f. 47 , op. 5 , d. $160,1.24$. 
uniforms, and local governments denied the RKM adequate office space in scarce city buildings. Most outlying police stations had no telephone contact with their central police headquarters, and very few police forces possessed adequate mechanized transportation for prisoner exchange, operational activities, or even to drive to meetings. ${ }^{20}$

If police networks were stretched thin across the Soviet territories in the early 1930 s, so were networks of the OGPU, at least according to the agency's own assessments. Before the formation of OGPU units in the system of machine tractor stations in 1932, total OGPU staff in the country varied from about 25,000 to 28,000 officers. This number included about 2,000 officials in the central apparatus and another 3,000 in OGPU school and prison administrative positions. Slightly fewer than 6,000 officers staffed regional bureaus of the OGPU or worked as special plenipotentiaries in regions. Another 700 to 800 officers worked in OGPU bureaus in "population centers" outside of the major capital cities of the country. Another 3,283 officers made up special operational "sectors." These operational "sectors" were formed in each oblast' and krai (75 in all) and each was staffed with 20 to 30 officers. These were to be used for special operations and to supplement the staff of regional offices. Regional bureaus were supposed to be staffed with up to three officers, yet in the early 1930 s, only $20 \%$ of the country's rural regions were fully staffed. Most regions had at least two officers, but nearly one-third of all regions had only one OGPU officer. ${ }^{21}$ According to one OGPU official in 1931, GPU networks were spread so thin across the countryside that the police had a more thoroughly developed system of information and policing than did the OGPU.22

During the dekulakization and collectivization campaigns, of course, OGPU numbers in the countryside increased and were supplemented by special OGPU forces, party plenipotentiaries, and by the famous urban factory gangs and other activists sent to the countryside to help with collectivization. Yet, as the party and police scaled back dekulakization and collectivization campaigns, OGPU special units and other groups withdrew from the countryside. This withdrawal left the new state vulnerable to sabotage and criminal activity. By 1932, OGPU troops had withdrawn their protection from agricultural warehouses, farms, and other rural sites, as well as from many state industrial sites. OGPU numbers were also depleted as the result of the transfer of hundreds, if not thousands, of OGPU officers to work in the understaffed judicial and procuracy systems, the police, and other state organs. OGPU troops continued to maintain guard of railroad lines, key junctions,

20. GANO, I, f. 47, op. 5, d. 160, 1. Poor service and living conditions and corruption described above for police in Western Siberia reflected a national pattern. For similar descriptions for the whole of the RSFSR and USSR, see GARF, f. 393, op. 1, d. 24, 11. 12-15; GARF, f. 1235, op. 141, d. 910, 11. 24-40; GARF, f. 5446, op. 15a, d. 1130, 11. 8-9. See also Iagoda's 1934 critical review of poor performance and corruption in the Western Siberian police administration in GARF, f. 9401, op. 12, d. 135, document 13 .

21. N. V. Petrov and K. V. Skorkin, Spravochnik. Kto rukovodil NKVD, 1934-1941 (Moscow, 1999): 35-36.

22. GARF, f. 9415 , op. 5 , d. $475,1.7$. 
some major roads, and industrial enterprises of significance. Yet, even these forces were overburdened. In late 1931, A. A. Andreev, the transportation commissar, warned Stalin in a letter that the numbers of OGPU troops within the railroad system were "obviously insufficient" in order to keep the roads cleaned of kulak elements and to pressure rail administrators to fulfill their tasks. ${ }^{23}$ A November 1933 report from the Western Siberian Executive Committee to the Russian Federation Sovnarkom requested immediate and extraordinary funding for 300 new police officer positions. The request arose as a result of OGPU cutbacks. Storage warehouses, timbering sites, and machine and tractor stations in the region's major collective farms (kolkhozy) were no longer guarded by troops of the state's political police, the OGPU, nor even by regular police. Hired security guards - usually pensioners or demobilized Red Army soldiers - patrolled these and the region's other major industrial facilities. ${ }^{24}$

\section{Reform and expansion of the militsiia and OGPU}

Party and police authorities took serious steps to professionalize and expand both the regular and political police organizations. Throughout the Soviet Union, OGPU plenipotentiaries purged socially "alien" elements from the police, as well as those with criminal backgrounds. By mid-decade, police numbers had been expanded considerably, and many of the new police officers were either de-mobilized army veterans or had been transferred from work in the OGPU. If in 1930, total police forces in the country numbered about 87,000 , by late 1932, Iagoda reported a total force of 98,000 officers..$^{25}$ Figures for mid-decade are scarce, but by late 1934, Iagoda counted 124,000 police in a report to Sovnarkom. ${ }^{26}$ By 1937, RKM forces had grown to a strength of 138,000 . With the formation of the railroad police in 1937 and the expansion of special economic crime units, overall police numbers jumped, reaching 182,000 in 1938 and 213,439 officers by 1940.27

23. A. V. Kvashonkin et al, eds, Sovetskoe rukovodstvo. Perepiska, 1928-1941 (Moscow, 1999): 165-166,

24. GARF, f. 5446, op. 14a, d. 762, 11. 7-8. Apart from the OGPU and the militsiia, two other types of police forces operated. The vedomstvennaia militsiia, or vedmilitsiia, were employed by enterprises as guards and patrol police. At times, the vedmilitsiia also patrolled the neighborhoods bordering on the enterprise if, as was often the case, there was no regular police presence in the area. Within the RSFSR in the summer of 1931, according to a VTsIK report, vedmilitsiia numbered close to 57,000 while regular police numbered 44,433. GARF, f. 1235 , op. 141, d. 910,1.40. A large number of vigilante police organizations also operated throughout the country. The RKM classified these under the rubric of voluntary associations for cooperation with the police, or obshchestva sodeistviia militsii (osodmil). The osodmil movement grew rapidly in the early 1930s for various reasons, but often in the absence of organized police protection. In early 1930, some 2,500 osodmil cells had organized spontaneously, involving 26,177 individuals, but by spring of 1935 , over 325,000 cells existed. Most, 245,000 operated in rural areas. GARF, f. 393, op. 84, d. 24, 1.21; GARF, f. 9401, op. 12, d. 135 , doc. 21 .

25. GARF, f. 5446, op. 13a, d. 1320,1.5.

26. GARF, f. 5446, op. 16a, d. 1270,1.28.

27. GARF, f. 5446, op. 22a, d. 130,1. 22 and GARF f. 9401, op. 8, d. 58,1. 1, respectively. 
In 1932, in accordance with subordination of the police to the OGPU, financing of the RKM was transferred from impoverished local soviet budgets to the allunion budget of the country's chief political administration. As a result, work and living conditions of the police improved considerably from their low point at the beginning of the decade. By mid-1935, all police had been integrated into the same rationing and rank system as the political police units of the NKVD, the administrative successor to the OGPU. In an attempt to professionalize the militsiia, Genrikh Iagoda, the head of both the political and civil police - the OGPU and the RKM - applied the same disciplinary system to the civil police that governed the OGPU and later the NKVD. RKM budgets rose considerably year to year, though never enough for Iagoda, and much of the money went to hire more police and to train and equip them to a level comparable to the OGPU. Soviet authorities also spent money on political training courses to raise the level of political reliability of militsiia functionaries.

From the beginning of the 1930s, the RKM and OGPU were administratively intertwined. They became increasingly interrelated as the decade wore on. Iagoda's reform of the RKM in 1930 and 1931 brought it under effective if not formal administrative control of the OGPU at all levels. Officials working in the central apparatus were OGPU officers and were appointed through Iagoda. At the oblast level and below, the RKM continued to operate as a supposedly independent organization subordinate to local soviet councils. In fact, OGPU plenipotentiaries and inspectors oversaw cadre selection, accounting, and other administrative functions. As police began to expand the number of precincts in cities and regions, the head of each uchastkovyi (precinct) was supposed to be both an RKM and an OGPU officer. Formation of a central all-union police administration in 1932 further increased OGPU administrative control over the RKM, and the formation of the NKVD in summer of 1934 brought the RKM under complete control of the organs of state security. ${ }^{28}$

Instructions to police in the early 1930s made clear their new role, which differed significantly from their previous functions. Previously, police acted as a constabulary force. They had many duties, vaguely defined, but they had limited investigative and arrest powers, and in the area of crime fighting acted primarily to make initial inquiries. Criminal investigations were conducted by procuracy officials or, in the case of more serious and especially organized crimes, by the branches of the state's ugolovnyi rozysk, or special criminal investigation units. Police subordination to the OGPU required them now to take a more active role in the fight against crime, social disorder, and anti-Soviet activities. With the promulgation of a new "polozhenie" in 1931, police were to have greatly expanded investigative and arrest powers. In addition to these new powers, police were also supposed to become an active part of the state's system of social surveillance. Local

28. A similar process of subordination occurred with the state's border forces, internal security forces, and forces for convoying prisoners. See A. V. Borisov et al, Politsiia i militsiia Rossii, op. cit.: 142-143 and L. P. Rasskazov, Karatel'nye organy, op. cit., especially part III, "Karatel'nye organy v protsesse ukrepleniia administrativno-komandnoi systemy," 231-306. 
precinct officers, for example, were required to establish a surveillance system of their neighborhoods that relied on regular information gathering from doormen, shop keepers, shoe-shine men, waiters and other service personnel. Using the passport card index that was supposed to be kept in every precinct, the uchastkovyi inspector was responsible for keeping track of all people coming in and out of the areas under his authority. ${ }^{29}$

Reforms of the RKM made clear Iagoda's intention to turn the police into an organ of social control subordinate but equal in preparedness to the organs of state security. By placing the police under the administrative control of the OGPU, Iagoda intended to "militarize" or to "chekaize" (chekaizatsiia) the police, but he did not intend for administrative merger to lead to operational merger. Officials attempted to keep police and the OGPU activities separate since they believed, at least still in the early 1930s, that there was an ideological as well as an operational difference between the functions of social control and state security. The police were to work as an auxiliary force to the OGPU in the establishment of social discipline and the protection of state interests and property, but the fight against counter-revolutionary activities was to remain a prerogative of the OGPU, the organs of state security.

The distinction between social control and state security soon broke down. The most significant overlap occurred at first between operational sectors of the OGPU and the police criminal investigative forces, the ugolovnyi rozysk. At times these groups either overlapped in their work or even stumbled into each other's operations, since both organs ran agent and informant networks and conducted special operations against organized crime. The OGPU, and Soviet officials in general, regarded organized criminal activity as more than a problem of social deviancy or even as an economic threat to the state. As one OGPU official declared, agents saw the hand of counter-revolution behind all forms of organized criminal activity. ${ }^{30}$ As a result, officials regarded organized economic crime - banditry, for example, and even some forms of group hooliganism - to be anti-state as well as socially harmful crimes. The definition of these types of crimes as both politically and socially dangerous led to operational overlap between the OGPU and the forces of the ugolovnyi rozysk, and this operational overlap led some officials to recommend a formal merging of the ugolovnyi rozysk and the OGPU. ${ }^{31}$ The two organs never formally merged, and neither did the regular police and the OGPU. However, the operational and "ideological" distinction between the police and OGPU broke down almost from the beginning of the 1930s as officials conflated economic and social control with state security.

If civil police investigators encroached on the operational territory of the political police, OGPU officers in turn soon found themselves unexpectedly involved in the business of social control and the maintenance of public order.

29. See Iagoda's instructions to police in GARF, f. 5446, op. 15a, d. 1130, 1. 2.

30. GARF, f. 9415 , op. 5, d. 475, 1.6-7.

31. GARF, f. 9415 , op. 5, d. 475, 1.12. 
Political police involvement on the railroads provides a good example of how this process occurred. Ostensibly, the OGPU's transport forces were charged to "defend" the railroads against counter-revolutionary sabotage, that is, against the enemies of the state. In practice, OGPU officers brought order to the railroads by providing protection to passenger trains from robbery and gang violence. In the absence of regular police, OGPU operational groups routinely cleared yards, depots, stations, and facilities of gangs and drifters. OGPU units spent much of their time engaged in operations against the organized transportation of stolen or contraband goods and the organizations that used the railroads for criminal purposes. At times, OGPU officers even checked passenger tickets and commercial train manifests. During periods of severe breakdown, OGPU forces were given authority to place certain lines under OGPU martial law, taking over the actual administration of the road. Such was the case on the Omsk and Tomsk lines in Western Siberia in 1935 and 1936. For a period of six months spanning those two years, Lazar Kaganovich, then transport commissar, requested the OGPU to oversee the administration and operation of the road. ${ }^{32}$ OGPU forces did much to bring discipline to the railroad system, but their efforts resulted in a militarization of social order and a conflation of social discipline with political defense of the state.

The merging of social control and political defense of the state became a cornerstone of OGPU and NKVD policies during the mid-1930s. Yet this conflation was not just the result of organizational "drift" or colonization of authority by the political police. Stalin set the tone for this shift in policy as early as January 1933 in his remarks to the party's Central Committee plenary meetings. In his speech, Stalin emphasized that open class war had ended with the victory of collectivization and the successful dekulakization of the countryside. Stalin cautioned, however, that enemies of the Soviet state would continue their opposition to Soviet power. They would do so not through open organized opposition, but through more subtle forms of sabotage and subversion - the infamous tikhii zapoi - and, because of their weakness as a social force, would seek alliance with other socially alien populations, such as criminals and other marginals. Criminality and lack of social discipline, said Stalin, now posed the greatest single danger to the construction of socialism in the USSR. The state needed to use all its measures of repression against laxness and this new kind of class war.

This new understanding deeply influenced police and OGPU policies in the mid-1930s and turned the fight against crime, social deviancy — indeed, any kind of social disorder - from a matter of social control into a political priority in defense of the state. Socially harmful elements, sotsial'no-vrednye elementy, were

32. On the Tomsk line, for example, during 10 months of 1935 , there were 5,972 "incidents" (proisshestviia) which resulted in the breakdown of 166 locomotives, 38 passenger cars, and 1,256 freight cars. These crashes resulted in 59 deaths and 119 injuries, 62 kilometers of rail lines were torn up, and movement was halted for a total of 686 hours. RGASPI, f. 17, op. 120, d. $158,11.232-238$. For reports by the OGPU plenipotentiary in temporary charge of the line, see ibid.,11. 154-187. 
now to be regarded as also politically dangerous. With this pronouncement, OGPU officials saw their suspicions confirmed by the country's political leaders. Behind any criminal activity lay the hand of counter-revolution. Now, suddenly, petty and big criminals, alike, hooligans, and other socially marginal groups became the business not just of the civil authorities, but of the OGPU.

Following Stalin's lead, high officials in all branches of the state's punitive and judicial organs adopted the argument that social deviance was a major, perhaps the primary, political threat to the existence of the state. ${ }^{33}$ Iagoda, the head of the OGPU/NKVD, gave one of the clearest statements about the political danger of social disorder in an April 1935 speech to a gathering of senior police officials. "For us," declared Iagoda, "the highest honor is in the struggle against counterrevolution. But in the current situation, a hooligan, a robber, a bandit - is he not the real counter-revolutionary? [...] In our country [...] where the construction of socialism has been victorious [...] any criminal act, by its nature, is nothing other than an expression of class struggle." 34 We might assume that Iagoda exaggerated the significance of policing functions in order to inflate the morale of his audience of policemen. Yet Iagoda emphasized the same priorities in his regular reports to Sovnarkom and, according to his critics, the NKVD chief emphasized similar priorities even in his communications with the GUGB. According to Leonid Zakovskii, a senior OGPU/GUGB official under Iagoda, the latter stressed protection of state property as the foremost concern for OGPU operational and territorial organs in the struggle against counter-revolution. According to Zakovskii, Iagoda laid out this priority in one of his first directives as head of the NKVD in August 1934. Zakovskii, as well as other critics such as Iakov Agranov, Iagoda's assistant chief, claimed that Iagoda maintained this emphasis in his operational administration of the GUGB, even after the murder of Leningrad party head, Sergei Kirov in December 1934. ${ }^{35}$ By and large, Iagoda's critics were correct about his policy priorities. Throughout the 1930s, Iagoda understood that the maintenance of social and economic order was the primary task of the NKVD in defending the political interests of the Soviet state.

33. See, for example, N. Krylenko's comments in N. Krylenko, "Proekt ugolovnogo kodeksa Soiuza SSR," Problemy ugolovnoi politiki, kniga 1 (Moscow, 1935): 21, 23; G. Volkov, "Nakazanie v sovetskom ugolovnom prave," Problemy ugolovnoi politiki, kniga 1 (Moscow, 1935): 74; A. Vyshinskii, "K reforme ugolovno-protsessual'nogo kodeksa," Problemy ugolovnoi politiki, kniga 1 (Moscow, 1935): 35.

34. GARF, f. 9401, op. 12, d. 135, document 119,1.2. I am grateful to Paul Hagenloh for help in reconstructing Iagoda's speech. For a more complete description of this speech, see Paul Hagenloh, "'Socially harmful elements' and the Great Terror," in Sheila Fitzpatrick, ed., Stalinism: New directions (New York, 2000): 286-308

35. RGASPI,f. 17, op. 2, d. 598,1. 12 and 41-43, respectively. These remarks were made at the February-March 1937 plenum. Again, given the highly politicized and scripted nature of that session, we should approach these comments with caution. Still, in substance, they seem to be an apt description of political police policy during the mid-1930s. See also Iagoda's directive to operational departments of the UGB, as well as the police, in March 1936 to free themselves from unnecessary tasks and to "focus on priorities of aggravated robbery, murder, and theft of socialist property." GARF, f. 9401, op. 12, d. 135, doc. 31,1. 4. 


\section{The mid-1930s: Social order and state security}

By the early months of 1936, Iagoda was able to paint a generally favorable picture of the NKVD's efforts to fight crime and to establish social order. His March 1936 report to Sovnarkom stood in sharp contrast to the dire outlines he had presented earlier in the decade. ${ }^{36}$ As the result of reforms, reorganizations, significant increases in personnel, and increased professionalism, Iagoda declared in his 1936 report, police had made significant advances toward the goal of securing social order and a reduction of criminality. Most violent crimes had been reduced to insignificant levels in the country. He boasted that there were fewer murders in the whole of the USSR in 1935 than in the city of Chicago. At the same time, Iagoda noted that certain types of crimes continued to be a problem, including simple robbery, organized forms of hooliganism, speculation, and theft of socialist property. While not as widespread as in the early 1930s, these types of crimes persisted, according to Iagoda, despite efforts of police to eradicate them. Lack of supervision of homeless children also continued to be a problem, and in 1934 and 1935 incidents of armed banditry also rose. According to Iagoda, professional qualifications and educational levels of the police had risen, as well as police discipline. Cases of corruption and crimes committed by police officers had fallen off considerably in the previous years, but Iagoda noted that still much had to be accomplished to raise the professional and "cultural" levels of the country's police force. ${ }^{37}$

Iagoda's internal NKVD report in early 1936 echoed the positive tone of his report to Sovnarkom. Overall, according to Iagoda, the police had secured order in the country and had achieved "notable successes" in the struggle to reduce crime. ${ }^{38}$ Yet whatever success the NKVD achieved in fighting crime and establishing social order was not due to the establishment of regularized policing methods in the country. Even by the middle 1930s, the country still had no effective constabulary system for the daily maintenance of order. Despite the growth in numbers, the number of police in the country in 1935 was still half what it had been before the 1914-1918 war. ${ }^{39}$ Police in most cities, even major urban centers, had yet to establish a police post system for daily patrols in neighborhoods. In provincial cities such as Novosibirsk, the large working-class neighborhoods in the city had no regular police patrol system. In Barnaul, an industrial pit five hours south of Novosibirsk by train, few police ventured out at all into the outlying shantytown districts of the city..$^{40}$ Attempts to establish night patrols, even in large cities, had largely failed and had been abandoned, and citizen vigilante groups continued to

36. GARF, f. 5446, op. 15a, d. 1130, 11. 2-10.

37. GARF, f. 5446, op. 18a, d. 904,11. 2-14.

38. GARF, f. 9401 , op. 12 , d. 135 , doc. $31,11.1-5$.

39. Iagoda's assessment. GARF, f. 5446, op. 18a, d. 904,1.2.

40. GARF, f. 9401, op. 12, d. 137,1.24; and doc. 14,11. 1-2. 
grow in areas that lacked effective police forces. Rural areas, according to Iagoda, remained outside the effective range of policing abilities. ${ }^{41}$

In the absence of regular policing, large-scale campaigns of mass repression continued to be the most effective means by which the NKVD fought crime and maintained social order. Throughout the middle 1930s, many tens of thousands of people were swept up in large-scale arrests and deportations, which did not end with dekulakization in the early 1930s. While mass arrests and deportations in rural areas tapered off after 1933, they increased in intensity and scope in urban areas and border zones as police attempted to purge these areas of criminals, marginal elements, potentially disloyal national minorities, and other undesirable or suspect social groups. GUGB and police operational groups continued to investigate largescale organized crimes, but crimes of small-scale speculation burgeoned out of control and were most effectively handled by mass police sweeps of markets, train stations, flophouse districts, and other areas where such people operated. The NKVD handled the single most troubling problem of social disorder during the middle 1930s - homeless youth and juvenile crime - in the same way. The other major problem that threatened social order during the 1930s stemmed from the various categories of "socially dangerous elements," and the regime handled this problem in the same manner.

\section{Passportization and mass repression}

The internal passport and registration system, initiated in early 1933 , became the primary instrument that police and the OGPU/NKVD used to protect the country against what were considered criminal and socially harmful elements. Initiation of the passport system was also the occasion for the first real administrative and operational meshing of the police and state security organs. Initially, the passport system was designed to deal with the consequences of mass dispossession and forced migration out of the countryside during dekulakization and collectivization. It was established specifically to seal off major "socialist" spaces (major cities, industrial zones, and border areas) from contamination by "superfluous people, those not tied to productive labor, kulaks fleeing to cities, criminals, and other antisocial elements." In other and later variations, anti-social became interchangeable with anti-Soviet. ${ }^{42}$ By August 1934, initial passportization of major cities in the Russian republic, and in the Moscow and Leningrad oblasti resulted in the issuing of 27,009,559 passports. Police issued about 12 million passports to citizens living in so-called "regime" cities, that is, cities on privileged supply lists and of special significance, either political or economic. Nearly 15 million passports were issued to citizens living in non-regime cities. ${ }^{43}$

41. GARF, f. 5446, op. 18a, d. 904,1.3.

42. RGASPI, f. 17, op. 3, d. 907,1.10..

43. GARF, f. 1235, op. 141, d. 1650,1.31. 
Passportization allowed police officials to quantify what they believed were the number of socially alien elements in the country. Passportization also allowed the regime to locate, at least initially, the areas of the country most saturated with marginal and dangerous populations. In an August 1934 report to the Russian Federation Soviet Executive Council, Fokin, the head of the police passport department, counted 384,922 individuals who had been refused passports. This figure amounted to slightly more than $3 \%$ of the overall number of citizens who had been granted passports. In the border regions of Eastern Siberia, nearly $11 \%$ of the population had been denied passports, while $1.5 \%$ of the population of Leningrad oblast' and the western border areas of the country were denied passports. ${ }^{44}$ After initial passportization of Moscow, Leningrad, Khar'kov, Magnitogorsk and several other cities, authorities could count about 70,000 alien elements - fleeing kulaks, individuals under judicial conviction, escaped convicts, individuals deprived of voting rights (lishentsy), and those with no socially useful employment. This number amounted to $3.4 \%$ out of a population of $2,088,422$ who received passports. ${ }^{45}$

The process of passportization set the country's marginal populations in motion. Hundreds of thousands of people fled the regime cities and industrial areas, either as a consequence of being denied a passport or in advance of the passport campaign. Officials estimated that, in the course of the two to three months of the passport campaign, about 60,000 individuals migrated out of Moscow, 54,000 fled Leningrad, and 35,000 left Magnitogorsk. ${ }^{46}$ Overall, during the first half of 1933, Soviet cities experienced a total out-migration of nearly 400,000 people. This was the only period since the civil war years in which the population of cities actually declined, and it was exceptional for the period of rapid industrialization and urbanization during the $1930 \mathrm{~s} .{ }^{47}$

Anticipating a large population movement, police and OGPU officials set in motion their own populations, not only to count but to round up the country's alien and dangerous populations during the period of passportization. Throughout 1933 and 1934, the OGPU mounted a number of operations in various cities and in particular border and industrial areas. Some of these operations, while they coincided with passportization, seemed not to be connected directly to passportization, and required politbiuro approval. ${ }^{48}$ Most operations, however, were related to the passportization campaign and were conducted on the basis of specific OGPU operational orders. In preparation for these operations, OGPU leaders ordered police and OGPU units to compile lists of undesirables in their

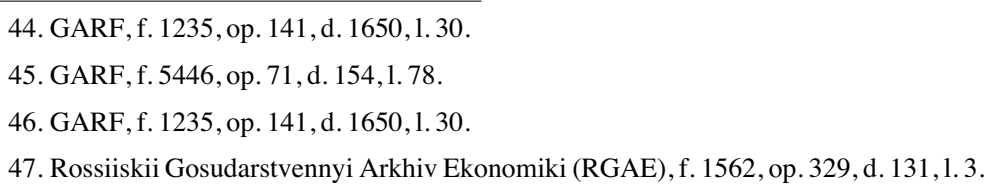
Magnitogorsk of criminal elements, and approval in January 1934 of an OGPU operation, to last three months, to sweep Khar'kov of déclassé elements. RGASPI, f. 17, op. 3, d. 914, 1. 3 and RGASPI, f. 17, op. 162, d. 15, 1. 164. 
districts, even before the issuing of passports. These lists were to be based on many sources of "compromising" information, but in particular on the basis of agent and informant operational work. This work was to be conducted by both police and OGPU operational groups. ${ }^{49}$ Police completed initial passportization of Moscow, Leningrad, Khar'kov, Magnitogorsk and several other cities by the end of March 1933, and the OGPU launched individual operations to sweep these cities of particular groups.$^{50}$ Special operations followed in other cities, but by late summer of 1933, the OGPU attempted to organize a systematic set of procedures to process the repression of undesirables. This was in keeping with the Central Committee's 8 May 1933 directive to cease campaign-style measures of repression and Iagoda's instructions to use the passport and registration system as a regular method of protecting cities. On August 13, Iagoda issued a circular, number 96, outlining the rules for the "non-judicial repression of citizens violating laws relating to the passportization of the population." This order established special passport troiki at the republic, krai, and oblast' level to review and sentence violators of passport laws. The troiki were to be chaired by the OGPU plenipotentiary who exercised control over the police, and its members were to include the head of the police passport department and the OGPU operational department, with participation of the local procuror. These troiki reviewed the cases of passport violators according to the lists sent to them from localities in their jurisdictions, and they were empowered to pass sentence on violators, subject to review by the OGPU Osoboe Soveshchanie, in Moscow. In his circular, Iagoda specified the kinds of sentences to be given for four categories of individuals: those with no useful employment and disorganizers of industry; lishentsy and kulaks, people who had been released from prison or sentences of exile (but who did not have the right to live in the city from which they had been exiled - DRS); and "criminals and other anti-social elements." The latter were to be sent to labor camps for up to three years, while those in the other categories were to be sent to penal re-settlement colonies (spetsposelki), or exiled to live outside a thirty-kilometer circumference from a passportized city. The order was especially hard on repeat violators (recidivists) in any category, who were to be sent to camps for up to three years. ${ }^{51}$

The work of the passport troiki yielded considerable results, which in turn reflected the extensive work of police and OGPU operational groups. In the last five months of 1933, the troiki for the RSFSR adjudicated the cases of 24,369 individuals who had been arrested under one of the above categories. Interestingly, nearly 17,000 of those arrested were freed, apparently convincing police that they were, indeed, upstanding citizens. In all, passport troiki convicted about 7,000 individuals, about 1,300 of which were sentenced to camps (konstlager'), 3,300 to

49. See for example the order for collecting information for sweeps of Moscow in GARF, f. 9401 , op. 12, d. 137 , doc. $1,1.1$.

50. See reports on operations in June and July to clear Moscow of gypsies, and in the same summer, to clear the city of déclassé elements. GARF, f. 9479, op. 1, d. 19, 11. 7,9.

51. GARF, f. 9401 , op. 12, d. 137, doc. 48, 11. 202-204. 
labor or other "special" colonies, and another 2,000 to "near" exile under the category "minus 30." 52

High police and state authorities intended the passport system to provide a daily means by which police could protect cities and other vital areas from penetration by socially harmful and anti-Soviet elements. Yet local police and OGPU officials continued to operate in the old ways, using campaign-style methods to clear their cities of undesirable and marginal populations. They did so very likely for several reasons. As Iagoda noted in his numerous reprimands of local organs, police did not appreciate the importance of daily maintenance of their passport offices as a way to combat the in-migration of undesirable populations. Moreover, most local authorities did not have the material resources and manpower to keep a constant registry of whom was coming and going in their precincts. And in the absence of these kinds of resources, police, especially under the influence of the OGPU/UGB, reverted to the methods of periodic campaigns or sweeps of their cities. Most OGPU/UGB operatives in the 1930s were veterans of the old ChK of the 1920s and early 1930s and were used to traditional chekist ways. Thus, Iagoda found himself constantly chiding local organs for neglecting daily passport control and then resorting to campaign-style methods, clearing cities of socially dangerous elements "in fits and starts." 53

The special powers of all OGPU troiki ended in summer of 1934 with the reorganization of the OGPU and the police into the NKVD SSSR. With this reorganization, all cases that had been adjudicated in non-judicial or administrative fashion were transferred for review within the country's restructured court system. This included all cases that had passed through the passport troiki as well as cases of counter-revolutionary and other state crimes that had been under the jurisdiction of other OGPU troiki. The only non-judicial body that was supposed to remain in operation after the 1934 reforms was the NKVD's Osoboe Soveshchanie, the special council in Moscow that adjudicated cases of counter-revolution and state crimes. Yet, the country's fledgling court system could not handle the crush of cases that passed through it, and soon the attempt to pass from administrative to judicial repression broke down.

Already in early January 1935, Iagoda and A. Vyshinskii, the procurator general of the USSR, gave instructions to re-establish special troiki to handle cases of passport violations by "criminal and déclassé elements." These special "police" (militseiskie) troiki were similar in makeup and function to the recently disbanded OGPU passport troiki. They were to operate at the republic, krai, or oblast' level,

52. GARF, f. 1235 , op. 141 , d. $1650,1.19$.

53. GARF, f. 9401, op. 12, d. 135, doc. 14, 1. 2. Iagoda singled out Western Siberian officials for particular though by no means unique criticism, noting that police in March 1934 had launched operations that led to the arrest of 4,000 undesirables, but had only arrested 300 the following month. In December of the same year, the district's party secretariat reprimanded M. Domarev, head of the district's militsiia, for failing to step up passport sweeps in the district. The party's reprimand instructed the police chief to intensify his efforts and to present a plan for 1935 "to purge the most important cities of Western Siberia of déclassé elements." GANO, II, f. 3 , op. 1, d. 550, 1. 18. See also GARF, f. 5446, op. 16a, d. 1270; GARF, f. 9401, op. 12, d. 137,1. 24. 
and included the appropriate head of the UNKVD (who was the administrative head of the UGB), the head of the corresponding level URKM, and the corresponding procurator. In a letter to Stalin from April 20, Vyshinskii explained that the formation of these troiki had been necessary due to the significantly large number of passport cases of socially harmful elements. These cases had clogged the judicial system and the Osoboe Soveshchanie. They had led to overcrowding of preliminary holding cells and the consequent violation of Soviet law for holding individuals without indictment. Vyshinskii was writing to Stalin for approval of a draft Central Committee directive that would give approval to the continuation of these troiki for operations that would "achieve the quickest clearing (bystreishaia ochistka) of cities of criminal and déclassé elements." ${ }^{4}$

Vyshinskii's draft was short, but in that draft, he stated, interestingly, that one of the primary functions of the troiki was to hear cases of criminal and déclassé elements "for which there is no foundation for transfer to a court." In other words, the troiki were designed to simplify the process of repression of undesirable populations by bypassing the judicial system's normal requirements for submission of evidence. Thus, the troiki could convict and pass sentence on an individual whose case might be quashed (prekrashcheno) by a regular court for lack of evidence. In order to preserve legal sanction, according to Vyshinskii, sentences for these types of cases were to be confirmed by the Osoboe Soveshchanie on condition that there was no objection from the procuracy at any level. ${ }^{55}$ In a note at the top of Vyshinskii's letter, Stalin replied that a "quick clearing is dangerous." Stalin recommended that clearing the cities should be accomplished "gradually, without jolts and shocks (bez tolchkov)," and "without superfluous administrative enthusiasm (bez...izlishnego administrativnogo vostorga)," that is, without administrative excesses. Stalin recommended that operations based on the directive last one year. With the rest of the draft, Stalin agreed..$^{56}$

\section{Order 00192 and other operations}

The actual Central Committee directive is not yet available in declassified archive materials, but it became the basis for some of the largest NKVD campaigns of mass repression during the mid-1930s. On May 9, 1935, Iagoda and Vyshinskii sent a joint set of operational instructions, order number 00192, to all republic, oblast ${ }^{\prime}$ and krai level NKVD administrations detailing the work of the new troiki. The substance of these instructions is worth noting since they show the extent to which the definition of socially harmful elements had broadened. In the 1920s, police defined socially dangerous elements narrowly as people with a criminal record. While they were suspect, they were generally not subject to summary arrest simply

54. RGASPI, f. 588, op. 2, d. 155, 11. 66-67.

55. RGASPI, f. 588, op. 2, d. 155,1. 67.

56. RGASPI, f. 588, op. 2, d. 155, 1.66. 
because of their socially deviant or marginal background. According to the new decree, however, socially harmful elements fell into one of several categories: persons with previous criminal convictions and (my italics) "continuing uncorrected ties" to the criminal world, and persons with no criminal convictions, but with no definite place of work and ties with the criminal world. The category also included "professional" beggars, persons caught repeatedly in urban areas without proper residence permits, persons who returned to places where they were forbidden to live, and children over the age of twelve caught in a criminal act. All of these types of people were to be regarded as socially harmful. They were now subject to summary arrest and sentencing by the extra-judicial troiki of the NKVD for up to five years in corrective labor camps. ${ }^{57}$

Operations based on the 9 May 1935 directive continued at least through the early months of 1936 . Sweeps by police and UGB units targeted particular city areas, especially flop-house districts, where large numbers of itinerant workers and vagabonds slept; they focused on shanty towns in industrial districts, market places, train stations and other urban public places, and on particular farms and villages. By the end of the year, operations by the police, alone, netted close to 266,000 people classified under the rubric socially harmful elements (sotsial'no-vrednye elementy). Approximately 85,000 of these individuals came under the jurisdiction of NKVD troiki, while the cases of another 98,000 were sent for hearing within the regular court system. In October, alone, police in the capital, Moscow, and in the Moscow oblast', detained nearly 6,300 people for not having proper residence and work documents, or for other reasons that defined them as socially dangerous types. By November, police had brought in 26,530 people in Leningrad, and in Moscow city by the same month, $38,356.58$

Operations against socially dangerous elements in Western Siberia mirrored trends in the rest of the country. The numbers of people swept up in these operations in that district were not as high as in oblasti of major cities such as Moscow, Leningrad, or Sverdlovsk, nor as high as the numbers in the Far Eastern district and in the always troublesome Black Sea district, but operations in Western Siberia ranked among the most extensive. Police pulled in close to 9,000 individuals by November 1935. NKVD troiki convicted about half that number, while the cases of the rest were sent through regular courts. Close to 1,800 individuals were eventually freed. ${ }^{59}$

57. GARF, f. 8131, op. 38, d. 6,1.61. See also summary of the decree contained in the records of the Western Siberian Procurator's office. GANO, I, f. 20, op. 1, d. 220, 11. 32-33. For further work on passportization and socially dangerous elements, see P. Hagenloh, art. cit;; Nathalie Moine, "Passeportisation, statistique des migrations et contrôle de l'identité sociale," Cahiers du Monde russe, 38, 4 (1997): 587-600; Gabor Rittersporn, "The impossible change: Soviet legal practice and extra-legal jurisdiction in the pre-war years." Paper given at the University of Toronto, March 1995; D. R. Shearer, "Crime and social disorder," art. cit.

58. GARF, f. 9401, op. 12, d. 135,1. 148.

59. GARF, f. 9401, op. 12, d. 135, 1. 148. 
The chief prosecutor of Western Siberia, I. I. Barkov followed the general line laid down by Vyshinskii. As interpreted by Barkov, the decree on socially dangerous elements provided the NKVD with a powerful weapon in the fight against criminals and other enemies of Soviet order. He declared that the new authority given officials under this decree allowed "a maximization of effort to sweep away criminal-déclassé and itinerant (brodiachie) elements, to reduce crime significantly, and to liquidate especially aggravated assault and armed robbery." ${ }^{60}$ Regardless of what he may have thought privately, Barkov publicly saw no contradiction between the principles of socialist legality and the use of such extrajudicial police methods against harmful populations. When it came to cases processed through the judicial system under statutes of the criminal code, Barkov hounded militsiia and UGB officials constantly for their investigative sloppiness, violations of procedure, and abuse of rights. Yet he only rarely criticized police activities related to these administrative forms of repression..$^{61}$ In keeping with the language of the 9 May instructions, Barkov recommend that police avoid "campaign-like mass operations," but in the same sentence he urged an increase in "daily sweeps of criminal-déclassé elements."

Police and UGB groups framed other operations against populations the regime perceived as harmful or politically dangerous. By May 1935, even before the formal establishment of the police troiki, NKVD sweeps of Leningrad oblast' and the Karelia border regions led to the deportation of 23,217 "kulak and anti-Soviet elements" to special labor colonies in Western Siberia and Uzbekistan. ${ }^{63}$ UGB units, using police and local party activists, also began large-scale deportations of suspect national minorities to Siberia and Central Asia, especially from the Western and Far Eastern border zones. In the two years, 1935 and 1936, UGB operations targeted tens of thousands of Finnish, Polish, German, Korean, and Ukrainian populations living in border areas whom the regime suspected of cross-border loyalties ${ }^{64}$ In 1935, Iagoda also recommended the removal of several thousand Soviet citizens of Greek origin living in the Black Sea border regions..$^{65}$

The regime regarded these populations with suspicion, especially within the context of rising international tensions during the mid-1930s, and party and state leaders regarded it as entirely within the authority of the state to remove these populations as a precautionary measure. Yet officials did not regard these populations as ipso-facto anti-Soviet. Even the populations that were to be resettled were not supposed to be deprived of their rights as Soviet citizens. Vyshinskii insisted, for example, that the "Greeks" to be moved from the Black Sea areas were

60. GANO, I, f. 20, op. 1, d. 220,1.32.

61. See, for example, GANO, I, f. 20, op. 1, d. 220, 11. 1-1ob.

62. GANO, I, f. 20, op. 1, d. 220,1.32.

63. GARF, f. 9479 , op. 1s, d. 30, 11. 13-14b. I am grateful to Lynne Viola for this and other references to f. 9479 .

64. T. Martin, art. cit., especially 847-850.

65. See the exchange of opinion about this proposal in GARF, f. 8131, op. 37, d. 59, 11. 183-98. 
to be compensated for their dislocation. Party, police, and UGB officials were supposed to distinguish carefully between those who were to retain their rights and those who should be categorized as socially dangerous or anti-Soviet. The latter were to be arrested, or if not arrested, processed and sentenced through special troiki to camps or labor colonies. In some instances, high GUGB officials provided operational officers with approximate figures of how many individuals to arrest or detain as dangerous. ${ }^{66}$

The mass operations against sotsvredelementy and national minorities worked so well that the regime applied the same methods to resolve a number of other major problems. Sweeps of orphan children became the primary method, for example, to resolve the problem of juvenile homelessness and gang crime. Over the course of the two years 1934 and 1935, Iagoda and the NKVD won out over more moderate solutions to these problems, and by spring 1935, police were engaged in mass roundups of street children, who were then sent to NKVD labor colonies. In effect, the takeover of the orphan problem by the NKVD criminalized this group in the same way that the law on harmful elements criminalized the unemployed and other socially marginal populations. ${ }^{67}$ Likewise, in July 1936, the Central Committee and Sovnarkom responded to problems of deficit goods and long lines by ordering police and UGB units to organize a campaign of sweeps against smalltime speculators. The joint government-party order took the form of a directive, dated 19 July 1936, signed by Molotov and Stalin. This directive ordered the police and UGB to submit a plan for a one-time sweeping operation, "using administrative procedures" in Moscow, Leningrad, Kiev, and Minsk. The directive provided a guide figure of 5,000 speculators to be arrested and processed through specially authorized troiki.68 By the end of August, according to Vyshinskii, troiki had convicted 4,000 individuals in the cities marked for special operations, while regular courts had convicted 1,635 individuals as part of the anti-speculators' campaign. The latter, however, represented figures from only 25 reporting oblasti and krai from around the country. ${ }^{69}$

In the absence of a regular policing system, the clearing or iz"iatie campaigns became the primary method for the regime to fight criminality and other forms of

66. GARF, f. 8131 , op. 37 , d. 59 , 11. 187-187ob.

67. D. R. Shearer, "Crime and social disorder," art. cit.: 128-130. See, for example, the police summary of expenses and other resources needed for mass operations against homeless and unsupervised children from July 1934 in GARF, f. 5446, op. 26, d. 18, 1.2 See also the Politbiuro-Sovnarkom commission recommendation for mass operations in summer 1934 in GARF, f. 5446, op. 71, d. 176, 1. 23. According to Iagoda, territorial and railroad police detained (zaderzhano) nearly 160,000 juveniles in 1935 as a result of sweeps. Of these, 62,000 were sent to NKVD camps or colonies. GARF, f. 5446, op. 18a, d. 904, 1. 6. According to VTsIK reports, police and UGB operations rounded up close to 62,000 children in the last half of 1935 and slightly over 92,000 children during 1936 . Close to 14,000 of these children were deported to NKVD youth labor colonies in 1935 and about 17,000 in 1936. GARF, f. 1235, op. 2, d. 2032,11.21-22.

68. GARF, f. 5446, op. 57 (1936), doc. 1285, 11. 124-128, 164.

69. GARF, f 8131 , op. 37 , d. 73,1 . 19. In all of 1935 , according to Iagoda, 104,645 individuals had been apprehended on charges or suspicion of speculation. GARF, f. 5446, op. 18a, d. 904, 1. 4 . 
social disorder, and to protect cities and other vital spaces, such as border regions and state resorts. Iagoda emphasized how well these methods had worked by noting in his March 1936 report to Sovnarkom that crime rates in the rural areas were not declining as rapidly as in urban areas. One of the main reasons, apart from fewer numbers of police, Iagoda emphasized, was that the government and party directives to clear cities of "parasitic and itinerant elements" had not been extended to cover operations in rural areas. ${ }^{70}$ In fact, because of the success of sweep operations, Iagoda recommended in his March report that Sovnarkom grant continuation of the work of the NKVD troiki to sweep déclassé elements from cities and workers' settlements. When queried for his reaction to this request, Vyshinskii replied that he had no objections in principle. He noted only that the matter needed to be discussed in a special commission, since there existed "special directives" governing the work of these troiki.71

Sovnarkom approved Iagoda's request. Lists compiled by the MVD in 1953 showed a total of 119,159 individuals sentenced by troiki in 1935 and 141,318 individuals in $1936.7^{72}$ Nearly three quarters of those sentenced by troiki in 1935 had been caught up in sweeps as sotsvredelementy under the NKVD order 00192. The next most significant category was very likely the category of national minorities, followed by groups caught up in smaller operations - speculators, thieves, rural agricultural disorganizers, and other criminal elements. No breakdowns of sweeps exist for 1936 in open archives, but the relative weights of categories probably remained about the same as in 1935. Interestingly, these numbers far outweigh the numbers of individuals who were sentenced specifically for counter-revolutionary crimes through the NKVD's Osoboe Soveshchanie (29,452 in 1935 and 18,969 in 1936.)..$^{73}$ About the same number of individuals were sentenced for major state crimes in 1935 as were sentenced by troiki (118,465 and 119,159 respectively). Yet, while the number of those convicted for high state crimes declined in 1936 to 114,383 , the number of individuals sentenced through troiki rose sharply in that year to 141,318.

Much has been written about numbers. They are the source of much historical contention. Figures for any category of arrest or repression can vary by the thousands, depending on which source one uses. Yet the figures above, combined with a close reading of operational orders and policy directives, show a clear trend. The Stalinist regime, the NKVD in particular, continued the policies of mass social repression, using administrative means, throughout the 1930s. The regime moderated policies of repression only in the sense that it curtailed the political repression of individuals under specific legal statutes of counter-revolution. Iagoda fell into line with the moderating tendencies of the mid-1930s over use of political

70. GARF, f. 5446, op. 18a, d. 904,1.3.

71. GARF, f. 5446, op. 18a, d. 904,1. 16.

72. GARF, f. 9401 , op. 1, d. $4157,1.203$.

73. GARF, f. 9401 , op. 1, d. 4157, 1. 203. In a letter to Stalin in March 1936, Krylenko cited a total of 24,737 individuals convicted for counter-revolutionary crimes in 1935, about 4,000 less than the figures compiled in 1953. GARF, f. 8131 op. 37, d. 73,1. 228. 
terror against the party and state apparatus. ${ }^{74}$ Yet, the NKVD under Iagoda, including the GUGB as well as the police, continued to use administrative methods of mass repression to achieve social order. In the middle years of the decade, the NKVD did not direct its campaigns of mass repression against peasants, but against a range of different and undesirable populations. Indeed, for Iagoda and for the NKVD, the struggle against social disorder was not only a social priority but also a political one. Iagoda, like many leaders, believed that, after the victories of dekulakization and collectivization, social disorder posed the greatest political danger to the state. Thus, the struggle against social disorder became, for him, the equivalent of political struggle against counter-revolution. While Stalin and other leaders supported this policy line at first, it became problematic after the murder of Kirov, and by late 1936, Stalin was ready to oust Iagoda for continuing this line in the operational policies of the NKVD. Ezhov's criticisms of the NKVD at the 1937 party plenum meeting reflected this turnabout. Ezhov's reforms of the NKVD after the February-March 1937 plenum reflected his attempt to separate the social order functions of the police from the functions of state security, which were supposed to belong to the GUGB. Administratively and operationally, Ezhov sought to re-orient the GUGB toward the fight against political opposition, understood not as social disorder but as direct, organized political subversion and spying. Thus, Ezhov jettisoned the economic crimes sector of the GUGB, which had drained so much operational time and energy. He placed responsibility for the fight against organized crime in the hands of a newly organized and strengthened police department, the OBKhSS (Otdel bor'by s khishcheniem sotsialisticheskoi sobstvennosti). In a major reorganization, and as a direct result of the FebruaryMarch plenum, Ezhov also created a new railroad police department within the structure of the GURKM. He clearly distinguished its functions from those of the newly reformed transport department of the GUGB. In a draft directive for the Central Committee, Ezhov outlined the functions of the new eleventh department of the GUGB. "The transport department of the GUGB," wrote Ezhov, "will be freed from functions of securing social order on railroad lines, maintaining public order in train stations, fighting against theft of socialist property, hooliganism and child homelessness. These functions are to be transferred to the newly formed railroad police, which will be subordinated to the GURKM NKVD." According to Ezhov, officers of the railroad department of the GUGB were to engage themselves exclusively in the fight against counter-revolutionary sabotage of the country's vital rail systems. Whatever this meant in practice is not entirely clear, but whatever Ezhov intended, it is clear that he wanted to get the GUGB - the organ of state security - out of the business of guarding mail cars, rounding up hooligans from train yards, chasing itinerant kids, robbers, and hobos riding on trains, patrolling train stations, and checking for ticket violations. ${ }^{75}$

74. On trends to reduce political terror against party and state officials, see Oleg Khlevniuk, Politbiuro: mekhanizmy politicheskoi vlasti v 1930-ye gody (Moscow, 1996).

75. GARF, f. 5446, op. 20a, d. 479,1. 36. 
Whatever other reorganizations Ezhov carried out is a matter of speculation. It is not known whether he streamlined and reoriented the work of the NKVD's agent informant networks, which he claimed needed to be done. Neither is it clear to what extent he purged the NKVD apparatus and fundamentally reorganized it. Despite his initial reforms, Ezhov never entirely separated the police from the GUGB. The government separated the two organs only in 1940, after Ezhov's brief but bloody tenure, and after the leadership of the NKVD passed to Lavrenti Beria. Yet, the separation of internal policing functions from the functions of state security began under Ezhov, immediately following the February-March 1937 meeting of the Central Committee plenum.

\section{The mass operations of 1937 and 1938}

Ezhov's criticism of Iagoda and NKVD policies was sharp and unequivocal. No one could have misunderstood his intent to change the previous policies of the NKVD. Just five months after the February-March plenum, in late July 1937, however, Ezhov issued the now infamous operational order 00447. That order began the mass operations of 1937 and 1938. By decree of the Politbiuro, the NKVD was charged to begin mass shooting or imprisonment of several categories of socially harmful elements. Leaders regarded former kulaks, bandits, and recidivist criminals among the most dangerous of these groups, alongside members of anti-Soviet parties, white guardists, returned émigrés, churchmen and sectarians, and gendarmes and former officials of the tsarist government. ${ }^{76} \mathrm{By}$ the end of November 1938, when leaders stopped the operations, nearly 766,000 individuals had been caught up in the police and GUGB sweeps. Nearly 385,000 of those individuals had been arrested as category I enemies. Those who fell into this category were scheduled to be shot, while the remaining arrestees, in category II, were to receive labor camp sentences from five to ten years. ${ }^{77}$

How are we to understand these operations and the order that initiated them? The mass operations of 1937-1938 seem to have been a direct contradiction of Ezhov's new turn in the NKVD. Except for the scale and the level of violence, the mass operations of 1937-1938 were similar in almost every detail to the kinds of campaigns that Iagoda had conducted against marginal populations and criminal elements. The mass repressions involved the same kind of operational procedures - procedures that Ezhov had condemned - and were directed against similar kinds of social groups - groups that Ezhov had declared were not the affair of the organs of state security. Once again, GUGB officers and units, in addition to the police, found themselves in the business of large-scale social purging. In campaign style, they rounded up criminals, itinerants, beggars, gypsies, so-called kulaks, and a host of other categories of suspect people.

76. Izvestiia TsK KPSS, 10 (1989): 81-82; Trud,(June 4, 1992): 4.

77. Marc Junge and Rolf Binner, “Tabelle zum Befehl 00447,”, p. 595-614. 
The return to mass social repression also seemed to belie the success of Iagoda's policies. In his March 1936 report on crime, Iagoda informed Sovnarkom that, with a few exceptions, the problem of social disorder had been resolved. Rates for nearly every major crime had declined, and although he recommended extension of campaigns against socially harmful elements, Iagoda looked forward to an increasingly stable social situation. Finally, there seems to have been no warning or discussion within the ranks of the party elites about the need for mass purging. In previous campaigns, whether against kulaks, national minorities, or deviant populations, party leaders had prepared the groundwork with widespread propaganda campaigns. No such groundwork was laid for the mass operations of 1937 and 1938. The Politbiuro resolution of July 2, on which order 00447 was based, seemed to arise out of nowhere. Certainly, mid-level party officials, such as Robert Eikhe in Western Siberia, were aware of the continuing problems in their districts, and Eikhe, for example, communicated those difficulties to higher party authorities. Discussions at the level of the Central Committee and in the Politbiuro show that concern existed at the top of the party hierarchy about continuing problems of social and economic disorder. Yet there is nothing to indicate that officials perceived a growing threat from social disorder, or a threat in any significant way greater than in previous years. Neither does there appear to be any discussion at higher party levels that would have led to the decision to engage in mass operations against such large numbers of people.

Still, the language that officials used in describing marginal and undesirable populations changed suddenly in the summer of 1937, and the change in language is indicative of the origins of the mass operations. NKVD and party authorities had long seen a link between criminal and other marginal populations on the one hand, and anti-Soviet, even counter-revolutionary elements, on the other hand. In the early summer of 1937, however, NKVD and party authorities began to perceive what they believed were active organizing efforts for fifth column activities in case of war with Japan and Germany. I believe Oleg Khlevniuk is correct in his argument that the decision to engage in mass operations against suspect populations was tied to Stalin's reading in early 1937 of rear-guard uprisings against the Republican regime in Spain during that country's civil war. As Khlevniuk argues, Stalin feared that enemy states might attempt to organize the same kind of rear-guard uprisings, which would threaten the country, should war break out and hostile powers such as Germany and Japan invade. ${ }^{78}$

In fact, this is the language that appeared in NKVD reports about suspect populations in Western Siberia in the early summer of 1937. It is the language of "rebellious moods" and fifth-column activities by foreign-directed agents and organizations. Thus, in a report to Robert Eikhe from June 1937, Sergei Mironov, head of the Western Siberian UNKVD, described operations to root out "kadetmonarchist and SR organizations." These underground organizations, according to

78. Oleg Khlevniuk, “Prichiny ‘Bol'shogo Terrora': Vneshnepoliticheskii aspekt.” Unpublished paper. 
Mironov, had united under orders from the Japanese intelligence service into an overall organizational front called the "Russian General Military Union" (Russkii Obshchevoinskii Soiuz-ROVS). The organizations in this union were preparing a "revolt and a seizure of power" in Siberia to coincide with an invasion by the Japanese army. Mironov described the various branches of this union, which the NKVD had uncovered through its investigative operational work, and then he made the connection between the work of these groups and the problem of marginal and other suspect populations. "Consider," wrote Mironov, "that in the Narym and Kuzbass areas there are 208,400 exiled kulaks; another 5,350 live under administrative exile and include white officers, active bandits and convicts, and former [tsarist] police officials [...] This is the social base for their organizing work [i.e., organizing work of the ROVS] - kulaks and penal settlers (spetspereselentsev) scattered across the Narym and in the cities of the Kuzbass [...] It is clear then the kind of a broad base that exists on which to build an insurgent rebellion." 79

This kind of language was different from the language of the mass operations to clear cities of harmful elements during the mid-1930s. It is a language that tied socially suspect populations to active military uprisings. This was a threat more dangerous than the threat of social disorder. Mironov's warning was not about the threat of social chaos, but about the formation of organized opposition. Mironov's language was a language consistent with Stalin's rising concern about the prospects of war and the domestic consequences of war. Mironov's assessment of the danger to the country from harmful populations also applied to rural as well as to urban areas. This rural aspect also distinguished the discussion about harmful elements in 1937 from previous assessments. The discussion about anti-Soviet elements in early summer of 1937 was not just about making cities safe for socialism; it was about the organized military threat that marginal populations posed throughout the entire country, and specifically in rural areas. In fact, Ezhov began order 00447 with reference to the countryside. He noted that ".... a significant number of former kulaks, those previously repressed, those hiding from repression, and escapees from camps, exile, and labor colonies have settled in rural areas." He wrote further that significant numbers of anti-Soviet elements - including sectarians, members of previous anti-Soviet parties, bandits, repatriated White officers, and others "have remained abroad in rural areas, nearly untouched." These, along with a "significant cadre of criminals" - including livestock rustlers, recidivist thieves, armed robbers, escapees, and others — posed a significant danger to the country as the source of "all sorts of anti-Soviet and diversionary crimes..." 80

Ezhov's assessment of the situation in the country reflected the paranoia of the day, but his description of the social dynamics of Soviet repressive policies during the 1930s was, for the most part, accurate. Previous mass operations had cleared the cities of suspect populations. Through passportization and clearing operations in

79. GANO, II, f. 4, op. 34, d. 26, 1.2.

80. See republication of this order in Iu. M. Zolotov, ed., Kniga pamiati zhertv politicheskikh repressii (Ulianovsk, 1996): 766-780. References are to p. 766. 
the mid-1930s, groups which the regime deemed anti-Soviet had been sent into exile or had been driven out of regime cities and border areas and had taken refuge in non-regime towns and in the countryside. There they had stayed, while many others had fled exile and camps, or had been released. The latter contingent was a sizable one, and included a significant proportion of those who had been dekulakized in the early 1930s and had served their five-year exile terms or had been released under the amnesty campaigns of 1934 and 1935. These groups were not allowed legally to return to their cities or regions of origin, and so many were, by the late 1930s, also living in rural areas and "unprotected" towns and cities. Thus, while the NKVD had secured the cities as "model socialist places" they had lacked the resources and, as Iagoda noted in March 1936, the authority, to extend that control to rural areas of the country. According to Ezhov, insufficient policing measures against these groups had, by 1937, permitted anti-Soviet elements that populated rural areas to begin to filter back into regime cities, industrial sites, into the transport and trade system, and into collective and state farms. Order 00447, then, can be seen as an attempt to extend and finish the job begun with the campaigns against harmful elements in cities from 1933 through 1936. The difference, of course, was the context of immanent war in which order 00447 was to be carried out. That context was missing in previous campaigns, and it gave to the mass operations of 1937 and 1938 their particular ruthlessness. Mass operations under order 00447 were to be mounted in rural areas as well as in towns and cities. These operations were to rid the entire country "once and for all," in Ezhov's words, of anti-Soviet elements.

\section{Conclusions}

The Soviet state's response to social disorder during the early and middle years of the 1930s provided the infrastructure that was eventually used for mass repression and surveillance of the population in the latter part of the decade. The dramatic increase in NKVD numbers and activities during the course of the 1930s, the establishment of widespread informant and agent networks and the change in police functions and methods from crime solving to social repression, the growing operational and administrative interaction between the militsiia and the OGPU/ GUGB, the social purging of cities and formation of the internal passport system - all this was created by the state in order to deal with the perceived threat of social disorder. Certainly, many officials hesitated to carry out political repression. Oleg Khlevniuk, among others, has documented this reluctance, even within the party structure, to use repressive measures during the middle 1930s. And as Khlevniuk, among others, has demonstrated, Genrikh Iagoda was very likely removed from his position in late 1936 for his slowness to respond to Stalin's perceived political enemies. Yet, whatever his faults in the sphere of party politics, Iagoda created the infrastructure of social repression that was used to its fullest in 1937 and 1938. 
As in the early 1930s, the regime turned on peasants during the Ezhovshchina, at least in Western Siberia. Collective and state farmers, as well as individual farmers (kolkhozniki, sovkhozniki, and edinolichniki) were "de-sovietized," which opened the way for their arrest in the tens of thousands. Yet, the mass repressions of the late 1930s were more than a second dekulakization. Criminal elements, former convicts, sectarians, and a host of other marginal populations, along with farm workers, local Soviet officials, and free-holder peasants, became targets of the state's campaigns of mass repression. As Terry Martin and others have shown, the repressions of 1937 and 1938 also encompassed significant numbers of national minorities. If the campaigns of mass repression began as a purge of socially suspect groups, they turned into a campaign of ethnic cleansing against "enemy" nations. ${ }^{81}$

Indeed, the threat of war introduced a national and ethnic element into Soviet policies of repression and gave to those policies a sense of political urgency. Soviet leaders had, for some years, feared the potential danger posed by populations that had national or ethnic ties beyond the borders of the Soviet Union. Large-scale deportation of certain ethnic populations started in 1935 and 1936 and coincided with the campaigns to clear cities of anti-Soviet and socially harmful elements. Deportations of national minorities continued under special orders throughout the late 1930s, but these operations also merged with mass repressions under order 00447. The repressions of the late 1930s combined an emerging xenophobia among Soviet leaders with traditional fears of political opposition and social disorder.

Here, then were the elements that gave the Great Purge its particular characteristics and virulence. The dekulakization and social order campaigns of the early part of the decade formed the background for the mass repressions of the late 1930s. The conflation of social disorder with counter-revolution, especially, influenced state and NKVD policies and methods: the mechanisms employed during the repressions of 1937 and 1938 were similar to those used earlier to dispose of undesirable populations and, in 1937 and 1938, the NKVD targeted many of the same social groups. Yet it was not the threat of social disorder, alone, that generated the mass repressions of the late 1930s. The fear of opposition political organizations - Trotskyists, Zinovievists, et al - revived after the murder of Sergei Kirov and merged with leaders' concern over control of marginal and other undesirable social elements. By 1937, leaders were convinced that oppositionists, working with foreign agents, were actively organizing socially disaffected populations into a fifth-column force. Authorities worried that invasion, which seemed increasingly likely in the late 1930s, would be the signal for armed uprisings by these groups. Each of these concerns - over social disorder, political opposition, and national contamination - had generated separate political responses and operational policies throughout the previous years, but they coalesced in 1937. The various fears of Soviet leaders combined in a deadly way within the context of immanent war and invasion. Ezhov launched the massive 
purge of Soviet society in 1937 and 1938 in order to destroy what Stalinist leaders believed was the social base for armed overthrow of the Soviet government.

The changing character of repression during the 1930s reflected the changing character of the Soviet state. In the early 1930s, party and OGPU officials directed campaigns of mass repression against what were considered hostile social classes, especially small-holding rural inhabitants. During collectivization and dekulakization mass repression was employed as part of a class war to establish Soviet power and the dictatorship of the proletariat. Ironically, the "victory" of socialism in 1933 and 1934 not only marked the end of class war; it also ended any pretense to class-specific forms of repression. Increasingly, officials justified repression in defense of the state, the gosudarstvo. With class no longer a primary criterion, repression encompassed an increasingly broad range of social and then ethnic groups. Soviet leaders believed that, in one way or another, these groups threatened social and political stability or the territorial integrity of the state. Having developed methods of mass repression early in the decade, the regime continued to employ and to systematize the use of these methods. Mass repression became the primary way authorities dealt with social disorder. In the process, mass repression became one of the main ways the regime redistributed the Soviet population, constructed politically acceptable national identities, protected the country's borders, and imposed social and economic discipline on Soviet society. Mass repression was more than a means to fight the state's enemies. Under Stalin, mass repression became a constitutive part of Soviet nation building.

University of Delaware

Department of History

Munroe Hall

Newark, DE 19716-2547

dshearer@udel.edu 